\title{
COMBATING RACISM: A NECESSARY FIRST STEP IN DEVELOPING PATHWAYS TO A DE-GOLONIZED FUTURE IN AUSTRALIA
}

\author{
SUZANNE JENKINS
}

\section{ABSTRACT}

The colonization of 'racial' groups was a key feature of the expanding British Empire in the $18^{\text {th }}$ Century. England's conquest of Australia resulted in the dispossession of Aboriginal and Torres Strait Islander peoples, marginalizing survivors on the fringes of colonial society while agents of British civilization actively sought to change and reshape their hearts and minds. To-day the question of race remains central to Australian politics, and therefore, to Australian life. For those who benefit, privilege is the norm, and as such lacks conscious scrutiny. For Aboriginal and Torres Strait Islander peoples, Australia remains a country where crimes against their humanity and cultural integrity go unnoticed, unheard or unpunished on a daily basis. Colonization remains a living process. This chapter offers a brief history of colonization in Australia and a comparative study of colonization in Cuba. It highlights how racism was used effectively in both countries to legitimize social inequality as natural, permanent and inevitable prior to the Cuban revolution. Current realities in both countries will be discussed with a view to learning from the Cuban experience. An argument will be presented illustrating how the effectiveness of models for decolonization, such as the Burgess 'five-stage model', or frameworks addressing 'truth and reconciliation' and 'transitional justice', are wholly dependent on the cultural, social, political and economic context in which they are applied. The chapter highlights the author's view that to succeed, any process to combat racism and support decolonization must engage with and overcome capitalism and imperialism at every level. 


\section{THE COLONIZATION OF AUSTRALIA}

The colonization of 'racial' groups was a key feature of the expanding British Empire in the $18^{\text {th }}$ Century. The faith held by the English in their culture, religion and laws was aided by their popular belief in the 'Great Chain of Being', a philosophy which regarded the Christian God as residing at the top of the Chain and 'civilized' Englishmen in the most elevated human position, close to angels and far above their colonized peoples. The English belief in their own cultural superiority fuelled their need to order the world, assume their right to 'civilize', and regulate and control the colonized.

In 1770, Englishman, Lieutenant James Cook charted the Australian east coast in his ship the 'Endeavour'. Cook claimed the east coast for King George 111 on the $22^{\text {nd }}$ August, 1770, at Possession Island, and (re)named eastern Australia 'New South Wales'. Nearly eighteen years later, Captain Arthur Philip, the first Governor of New South Wales, led the First Fleet, comprising 11 ships and approximately 1,350 people into Port Jackson on January $26^{\text {th }}, 1788$. Philip was under instruction to establish the first British colony in Australia. From 1788 until 1823 the colony of New South Wales was a penal settlement. Free 'settlers' started to arrive from 1793. The colonization of New South Wales led directly to Aboriginal and Torres Strait Islander dispossession, genocide, and forced assimilation.

The Australian landscape is unique. Differences in flora, fauna, and climate supported an Aboriginal and Torres Strait Islander understanding of the world that was fundamentally different to that held by the British invaders. Aboriginal and Torres Strait Islander peoples communicated their understanding of their country through stories, rituals, art and spiritual beliefs. The mutual incomprehension that existed between the British colonizer and, the soon to be colonized peoples was vast. When Captain Cook first encountered Aboriginal people in 1770, he recorded in his diary that:

They live in a tranquility which is not disturbed by the inequality of condition: the earth and sea of their own accord furnishes them with all things necessary for life; they covet not magnificent houses, household stuff etc., they live in a warm and fine climate, and enjoy a very wholesome air, so that they have very little need of clothing...They seemed to place no value upon anything we gave them...nor would 
they part with anything of their own for any one article we could offer them. This in my opinion argues that they think themselves provided with all the necessaries of life, and that they have no superfluities (Gott, 2011, p.85).

Naturalists and botanists, including the renowned aristocratic Joseph Banks, accompanied Cook on his ship the 'Endeavour'. Cook had been warned by the President of the Royal Society in London that "shedding one drop of blood of these (native) people is a crime of the highest nature...they are the natu$\mathrm{ral}$, and in the strictest sense of the word, the legal possessors of the several regions they inhabit" (Marr, 2012, p.357). Cook, however, was on a mission to claim lands for the British crown. Although he recorded how two Aboriginal men on the shoreline "seemed resolved to oppose our landing" (Gott, 2011, p.84), Cook declared the land 'terra nullius' 'empty land' or 'land belonging to no-one'. This remained the 'official' British/Australian position until it was overturned in the High Court of Australia in 1992. Sovereignty, however, has never been ceded by Aboriginal and Torres Strait Islander peoples over their lands, nor has a treaty been negotiated, leaving the constitutional status of 'Australia', increasingly under question.

Almost two decades after Cook's landing, the first British ships bearing convicts made their landing. For nearly a hundred years Britain had been sending convicts to its American colonies, while it enriched its empire through the exploitation of convicts and slaves. During the onset of industrialization, colonial markets, colonial supplies and colonial profits underpinned the rise and dominance of the British Empire. Britain's involvement in the African slave trade provided much needed seed capital for the Industrial Revolution. As Marx (1847) reported, slavery was indispensable during the period he described as the 'primitive' accumulation of capital. Slavery, he believed, made the colonies valuable and enabled the growth of world trade - a necessary precondition for large scale industry. Blackburn (1988) estimates in 1770, profits from slavery contributed in the region of $20 \%$ to $55 \%$ to Britain's gross national income. The historical record claims that Britain abolished the slave trade in 1807 and slavery itself in 1833. The developing economic system, however, gave birth to the idea of 'scientific' racism. This new ideology, capitalizing on Darwin's work (On the Origin of Species, 1859), allowed 'racial inequality' to be viewed as genetically inherited, thus providing justification for British imperial dominance through conquest and discrimination. 
With the loss of the American colonies, and faced with a fast growing urban population and high levels of unemployment resulting from the Industrial Revolution, Britain reached crisis point and needed to find an alternative location to transport its escalating number of convicts (Gott, 2011; Marr, 2012; Swiss, 2010). Joseph Banks was, at this time, a member of the King's Privy Council and the King's advisor on his Royal Botanic Gardens at Kew (Marr, 2012). When asked his advice for a suitable alternative location for a penal colony, he suggested Australia. On January 20. 1788, the First Fleet under the charge of Arthur Philip arrived in Australia with the first of 165,000 convicts. Philip was appointed to the first British Governor in New South Wales. Aboriginal hostility to Philip, his men and the convicts, was made as clear to Philip as it had been to Cook. Aboriginal attacks on the new arrivals were met with grim reprisals. Bonwick, a historian writing in the 1880s, (quoted in Gott, 2011, p.89) "described how 'a wholesale slaughter' became the usual mode of revenge adopted by the Christian strangers." Policies founded on racist ideology were used to justify the oppression and exploitation of Aboriginal and Torres Strait Islander peoples who were forced as bonded labour to work for pastoralists or build infrastructure for the new colonial economy.

At the beginning of the nineteenth century, imperial nations were engaged in a frantic international land grab. Initially however, Britain was unsuccessful in persuading its citizens to establish homesteads in the new colonies in Van Diemen's Land (Tasmania) and New South Wales. Advertisements designed to attract single women to a colony where men outnumbered women nine to one proved unsuccessful. The solution found to rectify this situation was to conscript a slave labour force using the Transportation Act (1718), which allowed convicts to be shipped anywhere in the world. Once the focus of the Act turned to procuring women, female petty thieves were targeted for arrest and prosecution. "Of the twenty-five thousand sent, fewer than 2 per cent had committed a violent crime, and 65 per cent were first offenders" (Swiss, 2010, p.13). The transportation of convicts to Australia continued until finally abolished in 1868 , just before a far greater migration was to occur largely due to the Australian gold rush.

The declining number of convicts sent by Britain to Australia in the 1850's resulted in Australia importing indentured labour from China and kidnapping (black birding) Pacific Islanders to work in mines, sheep farms and sugar cane fields. Also in the 1850's, rapidly increasing numbers of Chinese immigrants appeared in Australia attracted by the prospect of mining for gold. The name 
coined for these new migrates was the 'Yellow Peril'. During 1853 to 1857 this population rose from 2000 to 40,000 (London, 1970). The Chinese, regarded as being willing to work longer hours for lower wages than their (settler) Australian counterparts, were accused of stealing jobs belonging to white men. Racial hatred and fear of their comparative success in mining led to mobs of white miners driving Chinese miners off their stakes. Non-white workers were not allowed to join trade unions and were afforded little protection under the law.

\section{CREATING WHITE PRIVILEGE}

Those who come to dispossess and possess through violent force are often fearful they might fall victim themselves to the mantra of 'might is right'. One of the first laws passed by the newly established federal parliament of Australia in 1901 was the Immigration Restriction Act which banned 'non-white' immigration into Australia. This was known as the 'White Australia' policy, designed to create and maintain a uni-racial Australia. Aboriginal and Torres Strait Islander peoples who were resident outside Australia (taken as trackers to the Boer War, taken to play cricket in England) when the Act passed into law, were not allowed to re-enter Australia. The White Australia Policy was officially dismantled in 1975 when laws were enacted to ban racial discrimination (Australian Government Department of Home Affairs; London, 1970). The Racial Discrimination Act (1975) made it illegal to "offend, insult, humiliate or intimidate" someone because of their race (Section 18C). The current Coalition Liberal federal government is seeking to amend this clause of the Act.

Racism is, by nature, oppressive. It creates an environment in which a particular group finds itself in a devalued, often stereotyped position. Racism both reflects and is perpetuated by historical, social, cultural, power or authority inequalities in society. Racism and oppression in Australia have been described clearly in terms of their pervasive and systematic interventions, both within a historical and ongoing context. Aboriginal peoples have lived in Australia for up to 120,000 years (Dudgeon, Wright, Paradies, Garvey, \& Walker, 2014). Prior to colonization, the population was conservatively thought to be between 300,000 and 750,000, drawn across an estimated 500 clan groups, each having their own distinctive territory, history, language, dialect, and culture (Collard, 
2000). By the turn of the $20^{\text {th }}$ century, the population of Aboriginal and Torres Strait Islander peoples was reduced to an estimated 75,000 (Dudgeon et. al., 2014). Analysis of the United Nations criteria for acts of genocide has found Australia historically qualifies on four distinct grounds:

- the well documented killings of Indigenous people by settlers and 'rogue police' in the 1800's;

- the forcible transfer of Aboriginal children away from their parents "... with the express intent that they cease being Aboriginal" (Tatz, 1999, p.6. Author's emphasis);

- the attempt to achieve "... the biological disappearance of those deemed 'half-caste Aborigines" (Tatz, 1999, p.6), and finally,

- the mental or physical suffering inflicted on Aboriginals under 'protective' Government policies (Tatz, 1999).

Hunter (1993) highlights the historical nature of racism and oppression when he describes how British structuring and control of Aboriginal societies began in 1788 , and:

has since influenced every facet of Aboriginal lifestyle, including language, clothing, settlement, housing, food, economy, work, religion, education, law and health. The imposition of non-Aboriginal social structures such as missions, stations, orphanages and the bureaucracies of adoption, has been largely utilitarian, facilitating either the control of Aboriginal access to resources, or the availability of Aborigines, themselves, as a resource (p. 258).

Paradies and Cunningham (2009) describe racism as occurring across three different dimensions: interpersonal, systemic and internalised. As long as the dominant view dictates how issues are defined and responded to, alternative voices are robbed of their opportunity to be heard. Prior to the 1967 Citizen Rights Referendum, Aboriginal and Torres Strait Islander peoples in Australia were not counted in the nation's population census, but were instead listed under the category 'Flora and Fauna'. Following the Referendum, repression of Aboriginal and Torres Strait Islander culture was enshrined in the application process for accessing citizenship. Those who were able to apply for citizenship were required to formerly relinquish their cultural identity (Dudgeon, 2000). 


\section{THE REALITIES OF LIVING IN A 'WHITE WORLD': PRIVILEGE VERSUS DISADVANTAGE}

The study of 'whiteness' is an area of investigation, which concentrates attention upon the socially constructed nature of white identity and the impact of 'whiteness' upon relations with minority and Indigenous groups. Frankenberg (1993, p.236) defines 'whiteness' as “... the production and reproduction of dominance rather than subordination, normativity rather than marginality, and privilege rather than disadvantage." Vickers (2005, p.22) describes colonial, race-based societies as 'hierarchical' where "whiteness puts you at the top" and racial prejudice becomes "...the life blood of colonial rule and colonial society." Green \& Sonn (2006) refer to 'whiteness' as “... the dominance and privilege that comes from being white in countries like Australia" (p.379). In the words of Smith (1999, p.80) "They Came, They Saw, They Named, They Claimed."

A 2013 report by Credit Suisse reported that Australians, for the second consecutive year, were the second richest people in the world. The mean wealth per adult was just over US $\$ 400,000$, second only to Switzerland (Main, 2013). The Credit Suisse Global Wealth Report (2016, p.57) reported the average annual growth of wealth per adult in Australia, between 2000 and 2012, to be $12 \%$. According to this report:

Wealth inequality is relatively low in Australia, as reflected in a Gini coefficient of just $68 \%$ for wealth. Only $11 \%$ of Australians have net worth below USD 10,000. This compares to $22 \%$ in the UK and $35 \%$ in the USA. Average debt amounts to $21 \%$ of gross assets. The proportion of those with wealth above USD 100,000 at $55.8 \%$ is the fifth highest of any country, and almost seven times the world's average. With $1,688,000$ people in the top $1 \%$ of global wealth-holders, Australia accounts for $3.5 \%$ of this top slice, despite being home to just $0.4 \%$ of the world's adult population.

If Aboriginal and Torres Strait Islander peoples, who make up approximately 2.5-3\% of the Australian population, were surveyed as a stand-alone population, however, Australia's world rating would drop to $122^{\text {nd }}$, reflecting that many Aboriginal and Torres Strait Islander communities languish in third- 
world conditions despite Australia's wealth (Georgatos, 2013; Jenkins, 2015). In the 2018 Credit Suisse Global Wealth Report, Australia overtook Switzerland as the wealthiest country in the world with Australian billionaires increasing from 33 to 43, with a corresponding wealth increase of \$36-160 billion.

In December 2017, an Australian Institute of Health report (2017) found that mortality and life expectancy gaps are actually widening between Aboriginal and Torres Strait Islander peoples and non-Indigenous Australians. Australia has the world's fourth highest life expectancy at 82 years. For Aboriginal and Torres Strait Islander peoples, the gap can range between 10 to 30 years compared to non-Indigenous people. Mortality rates for Aboriginal and Torres Strait Islander peoples of all ages are twice that of non-Indigenous people. Dickenson diseases remain rife. Australia is the only developed country not to have eradicated trachoma, a condition that continues to blind Aboriginal and Torres Strait Islander children. Australia has the lowest suicide rate of the world's top 10 nations, but Aboriginal and Torres Strait Islander Australians have the highest youth suicide rates in the world. Nationally, suicide death rates are twice that of non-Indigenous peoples. The educational experience of Aboriginal and Torres Strait Islander children continues to reflect a picture of profound disadvantage in comparison to non-Indigenous children. An Aboriginal and Torres Strait Islander child is 40 times more likely to be in custody than a non-Indigenous child. Proportionally, Aboriginal and Torres Strait Islander Australians are the most incarcerated people on the planet. The removal of Aboriginal and Torres Strait Islander children from their families is now more widespread than at any time during the last hundred years, including the numbers of children forcibly removed during the 'Stolen Generations', deemed by the United Nations to be an act of genocide (Tatz, 1999). 90\% of the homeless people in the Northern Territory are Indigenous (Dudgeon et al., 2014; Georgatos, 2013; Jenkins, 2015; McQuire, 2013; Pilger, 2014). The list highlighting appalling disadvantage goes on and on. Euphemisms such as 'reconciliation' and 'stronger futures' continue to camouflage plans for social engineering and reflect an enduring insidious racism within the political elite, the bureaucracy, and the wider Australian society (Pilger, 2014). The Australian 'nation state' is built on racial crimes. From the first days of colonization, Australia was established and maintained through bloodshed and violence. Racial prejudice remains the lifeblood of colonial rule and colonial society. 
Acknowledging the explosive level of disadvantage suffered in Aboriginal and Torres Strait Islander communities, the Council of Australian Governments (COAG) in 2008 devised the 'Closing the Gap' strategy with a target to achieve life expectancy and health equality by 2030. The 'Close the Gap Statement of Intent' sought a compact between Australian governments and Aboriginal and Torres Strait Islander peoples, and embodied a human right to a health-based blueprint for achieving health equality.

The close the gap approach and the Close the Gap Statement of Intent is founded on an understanding that population health outcomes are fundamentally the result of underlying factors, such as social determinants, institutional racism, the quality of housing, and access to appropriate primary health care. If governments want to improve and sustain the health of any population over time, these elements must be addressed (Close the Gap Campaign Steering Committee for Indigenous Health Equality, 2018, p.3).

\section{"IN 1967 WE WERE COUNTED, IN 2017 WE SEEK TO BE HEARD" [ULURU STATEMENT FROM THE HEART, 2017.}

In May 2017, a historic First Nations National Constitutional Convention meeting at Uluru in Central Australia, led to a proposal known as the Uluru Statement from the Heart. This Convention was called following bi-partisan governmental agreement to seek the views of First Nation Peoples. The conversation at Uluru built on six months of discussions held around Australia where Aboriginal and Torres Strait Islander peoples considered five options presented to them. Among other objectives, the Uluru Statement sought to progress a Closing the Gap strategy which would be genuinely co-designed. The Uluru Statement made three core proposals:

1. An Aboriginal and Torres Strait Islander Voice enshrined in the Constitution;

2. A Makarrata (the coming together after a struggle) Commission to oversee agreement making between Governments and the Aboriginal and Torres Strait Islander peoples; and,

3. Truth-telling about our history, led by the Makarrata Commission (First Nation National Constitutional Convention, 2017).

These proposals have been summarily rejected by the Coalition Liberal federal government. 


\section{ARE THERE LESSONS TO BE LEARNED FROM CUBA?}

Where in the world can we look for inspiration in dismantling racial prejudice? Does another country share a common history? Yes, many. Have any been able to address racial prejudice sufficiently to develop a radically different picture? Maybe lessons can be learned from Cuba?

Spanish colonists first landed in Cuba, in Baracoca on the north-west coast, in 1511. The Indigenous peoples there at that time called themselves Tainos. A Dominican priest who arrived with the conquerors, commanded by Velasquez, described them as having "...food in abundance... they had everything they needed for living" (Gott, 2004, p.12). Velasquez had orders to settle the island for the King of Spain, but his men were greeted with fierce resistance which lasted decades. Settlement followed conquest. The Tainos were expected to surrender their land and supply the new settlers, arriving regularly from Spain, with food and labour. Many were massacred or died at their own hand, others were worked to death, while some apparently disappeared into the hills. The Tainos were destroyed as a continuing civilization and culture, an obvious difference to Aboriginal and Torres Strait Islander peoples who remain the longest continuous culture in the world (Collard, 2000). Replacements for the Tainos peoples were hunted from other neighbouring islands, but given the ever increasing demand for new labour, black slaves were eventually purchased from Africa. This was a trade that lasted over three centuries, and saw nearly a million Africans brought to the island. Like the Tainos before them, the African slaves were prone to rebellion which was ruthlessly crushed. Early fears of slave rebellion haunted the white settlers and led to deep divisions between black and white Cubans, such that racial prejudice was considered the greatest obstacle to securing Cuban independence from Spain. That is, until the emergence of Jose Marti, interim president of the Cuban Revolutionary Committee in exile. Marti was a hero of Cuban and Latin American history, and an outspoken advocate for racial equality (Gott, 2004). Marti was born in Havanna in 1853 to Spanish immigrants, who benefited from the 'white Cuba' program to 'whiten' the Cuban population through Spanish immigration. Marti offered strong leadership on the need for racial harmony. In a letter to Maceo, a military general in the anti-Spanish war, Marti states:

I have no time to tell you General, how in my eyes the Cuban problem needs, rather than a political solution, a social solution, and how the latter can- 
not be achieved except through mutual love and forgiveness between the two races...For me, the person who whips up hatred in Cuba, or takes advantage of those hatreds already present, is a criminal. And the person who tries to put down the lawful aspirations to livelihood of a good and prudent race which has already seen enough misfortune, is another (Gott, 2004, p.87).

Tragically Marti was killed in an ambush in 1895, aged 42. Jose Marti, the hero of Cuban independence, became the principal source of inspiration for Fidel Castro who described him as "a remarkable, a singular talent... What thought, what resolve, what moral strength! He formulated a doctrine, he propounded a philosophy of independence and an exceptional humanistic philosophy" (Castro \& Ramonet, 2006, p.146-147). Marti is honoured throughout the island of Cuba. Ironically the Castro family also benefited from migration from Spain after Angel Castro, Fidel and Raul's father, arrived in Cuba as a soldier from Galicia, the son of a poor farmer. Through his life, however, Angel Castro accumulated substantial wealth and land. This privileged background provides an interesting backdrop for the two Castro sons who would become world renowned revolutionaries. Following military success against the Batista regime on 2 January 1959, Fidel Castro announced, from a balcony in Santiago de Cuba, "The Revolution begins now," (Gott, 2004, p.165).

\section{THE REVOLUTION DELIVERS}

Castro's revolution had succeeded mainly through the efforts of white radicals. Black people were not very prominent, with a few notable exceptions, in the leadership of the revolutionary war. Cuba remained a country largely divided along racial lines. Slavery in Cuba had only been abolished for seventy-three years when the revolution succeeded in 1959. Recognising the need to address racial prejudice, Fidel made his first speech on the subject in March 1960, when he called for a campaign against racial discrimination. Whites-only facilities were opened to anyone or closed down, and equality was established under the law (Gott, 2004; Castro \& Ramonet, 2006).

The Cuban revolutionary government carried out a number of far-ranging socio-economic transformations. Large US owned industries were nationalized, privileges were removed from absentee and big real-estate owners, free health and education were provided for all in both urban and rural areas, and a national literacy campaign was initiated. The new government's inventive 
approach to addressing literacy on a countrywide basis with grassroots volunteer teachers, young and old, became a source of bonding among the Cuban people, and allowed Cuba to achieve and sustain a literacy success rating of 99\%. Through large public meetings, Fidel addressed new policy directions, including a new structure for elections, with millions of Cubans in what August (2013, p.107) described as “...groundbreaking in the annals of revolution, whereby leaders publicly exchange with the people in mass meetings and a dialectic bond is created in order to make decisions."These meetings resulted in active grass roots participation in creating socio-economic transformation, and in Cuban people developing their own unique political systems. People started to organize committees in their local communities, an action that spread throughout the country and led to the creation of the Committee for the Defence of the Revolution and the Federation of Cuban Women. This network of neighbourhood committees enhanced the operation of community participation through social and political actions (August, 2013). The gains made by the Cuban revolution for the Cuban people are immense, startling even in the context of the crippling US blockade against Cuba, which continues to this day. To have such policies applied to Australia today would indeed seem miraculous.

\section{IMPROVING ON THE BEST}

The Revolution's treatment of race equality is certainly recognised as one of its greatest achievements. But, was the main architect satisfied with the level of equality achieved? Speaking in 2006, Fidel stated:

There was no subjective discrimination. Because every revolutionary knows that among the cruelest sufferings that affect human society is racial discrimination....In this nation slavery was abolished 120 years ago, in 1886, although it was just in name, formally. Men and women subjected to that abominable system continued to live for almost another three-quarters of a century as apparently free labourers in rundown barracks and shacks in the country and in the city, too, places in which large families would have a single room to live in, without schools or teachers, doing the lowest paid labour...After the triumph of the Revolution, we were pretty ignorant about the phenomenon 
of racial discrimination, because we thought all we had to do was establish equality under the law, and that it would be applied without discussion...we were naive enough to believe that decreeing total and absolute equality under the law would put an end to discrimination. Because there are two types of discrimination - one is subjective and the other is objective...the people have achieved full and complete legal equality and a level of revolutionary education that has done away with most of the subjective component of discrimination, (racial discrimination) still exists today in another form. I call it objective discrimination, a phenomenon associated with poverty and a historical monopoly on knowledge...Even though you built new houses, the phenomena that occurred in that place tended to continue to occur, unless a new culture arises on the basis of education... The Revolution, over and above the rights and guarantees achieved for all citizens of whatever ethnic background or origin, has not had the same success in its fight to eradicate the differences in social and financial status for the black population of the country....But I am satisfied with what we are doing in terms of discovering the root causes, which, if you don't make a determined effort to do something about them, tend to prolong people's marginalization down through subsequent generations (Castro \& Ramonet, 2006, p.227-231).

The Revolution certainly created great social and economic improvement for the vast majority of Cuban people, but until a policy can successfully address profound discrimination and disadvantage, social and political gains remain unequal. According to Raul Castro in 2010 (quoted in August 2013, p.142143), “...several errors were made namely, an "excessively paternalistic, idealistic and egalitarian approach instituted by the Revolution in the interest of social justice", and "the excessively centralized model characterizing our economy." The government's naivety in trusting a top down approach to end racial discrimination was compounded by its lack of a political program specifically aimed to attract a black constituency, and by its lack of support for established black societies with agency which promoted black and African consciousness and allowed for grass roots expression of cultural and social concerns (Gott, 2004). By comparison, women, who according to Fidel were “...terribly discriminated against, with access to only the most humiliating work" (Castro \& Ramonet, 2006, p.235) were able to organize through the Federation of 
Cuban Women to become $65 \%$ of the technical and scientific labour force by 2006, and enjoy 48.86\% representation in the Cuban National Assembly following the 2013 national elections.

\section{FRAMEWORKS AND MODELS FOR DECOLONIZATION}

Discussion around Aboriginal and Torres Strait Islander rights continues to invoke fear in white Australia, and is regarded as a threat to the security of many non-Indigenous Australians. A movement away from colonization will only occur when non-Indigenous Australians participate in a debate, which will allow them to question their own institutions and ways of seeing (Watson, 2007). Only then will they truly hear Aboriginal and Torres Strait Islander voices and be able to relate to their experiences. The willingness of non-Indigenous people to engage in such a debate will inevitably lead to unsettling realizations, both historical and current. De Costa and Clark (2011, p.332) believe such debate should not be avoided as "the question of 'decentering' or 'unsettling' the settler within, may be the key..." to a decolonized future. We are all implicated in and through colonization. How we decolonize is connected to how exactly we are implicated. A decolonized future in Australia is not possible without commitment to change. It requires personal and collective commitment to social activism and revolutionary change. In preparing my presentation for the $4^{\text {th }}$ International Indigenous Voices conference held in Alta, I realized I was being drawn towards notions of 'truth \& reconciliation' with their strong, and possible dangerous, emphasis on trauma and healing, or 'transitional justice' - something familiar, a workable framework. Can transitional justice be incorporated into decolonization? Transitions can be rare periods of opportunity. Is it possible to develop a form of transitional justice that not only reveals and repairs past violence, but also develops new justice possibilities that fully recognize decolonization as central to the return of, and connection to, land? Addressing the legacy of past wrongs and challenging the continuation of current ones, needs optimal conditions and opportunities for sustainable healing. Burgess (cited in Muller, 2007) developed a five-stage model to support the process of decolonization. The stages are:

1. Rediscovery and recovery 
This first stage is referred to by Muller $(2007$, p.6) as a "foundation phase". It offers an invitation to:

...understand and acknowledge the process of colonization and to collaborate in the de-colonization process with Indigenous people. For those who profess social justice and human rights as central to the ethics of their profession, de-colonization offers a pathway to honouring these commitments and provides a framework of de-constructing the curse of colonization.

The past is always in the present. It is only by understanding the past that we become more able to critique the present and actively shape the future.

\section{Mourning}

The journey to decolonization will require a massive shift in understanding, and a new way of embracing both historic wrongs and unsavoury current realities. Past and current wrongs need to be addressed and issues relating to grief, loss, shame and anger acknowledged.

\section{Dreaming}

Dreaming involves imagining a better future for all Australians, and planning how this can be achieved. Through this process hope may be established, enabling progress to be made towards a more socially just society - one in which critique and possibility strengthen values of freedom and equality.

\section{Commitment}

Emerging from the dreaming phase provides the opportunity to move towards the type of society we wish to create. Change becomes possible when we accept who we are and commit to working towards achieving who we want to become.

\section{Action.}


In this stage the 'current picture' is transformed into the 'preferred picture' (Egan, 2010).

In 2014, Muller added a sixth stage 'healing and forgiveness' which she located between mourning and dreaming. In healing and forgiveness, Muller (2014) offered a space to reclaim wellbeing and harmony. She regarded this stage as both central to, and a goal of, decolonization. Other stages can be assessed from within this stage. "...it is possible to rediscover knowledge, mourn in safety, dream of a decolonized future, make commitments and take action from within Healing and Forgiveness" (Muller, 2014, p.231). Healing and forgiveness does not mean ignoring past wrongs or abandoning the right to justice, rather "...it is a stage where a person might find harmony within themselves and with others" (Muller, 2014, p.218).

In 2015, this author added a seventh stage 'acknowledging current realities', located before rediscovery and recovery. This stage involves highlighting how Aboriginal and Torres Strait Islander peoples suffer profound disadvantage and bear the burden of gross social, cultural, educational, health and employment inequality in Australia.

This (seven stage), model is neither linear nor sequential. It does not have rigid boundaries. The flexibility of the model allows it to be applied both on an individual and collective basis. The relative success of such a model, however, is wholly dependent on the cultural, social, political and economic context in which it is applied. Such frameworks and models do not engage directly with Indigenous resurgence and decolonization, so there remains a danger that the foundations, goals, and discourses of such practices may, in reality, become major impeding factors that block genuine decolonization and consolidate state power.

Decolonization is not an endpoint. The struggle for decolonization is a journey that is never ending. Any process of decolonization, however, must engage with capitalist imperialism and colonialism at every level. The Cuban revolution is a social project, based on the philosophy of socialism. Its aim is to provide for the economic and social wellbeing of the vast majority of Cuban people, not the unlimited accumulation of wealth for a few. Although Cuba may be considered an economically 'poor' country, a situation greatly exacerbated by the continuing blockade by the United States government, peoples' access to a voice through political participation and representation, free education and health care, and a literacy rate of $99 \%$ has effectively closed any 'gap' that existed along racial lines. 
Racial harmony cannot be achieved without strong leadership creating the conditions that will lead to the end of discrimination and offer real equality. Nor can it be successful if those most affected by the ravages of racism, are not empowered to take their rightful place in their own country. Aboriginal and Torres Strait Islander voices must be respected and heard in Australia! Aboriginal and Torres Strait Islander knowledges, ways of knowing, being and doing, are essential to challenging material greed and developing culturally appropriate purposes of relationally, mutuality and connectivity (Jenkins, 2015; Muller, 2014). Decolonization involves a critical analysis of Western-informed ideological frameworks and as such, is a process that must focus on the mechanism of our neoliberal market forces and offer a class analysis. The Credit Suisse Global Wealth Report (2016) may have described wealth inequality in Australia as relatively low, but this situation is changing rapidly. Australia has developed a "...distinctive, localized version of neoliberalism....that supports markets and citizens who invest in them in preference to non-market welfare" (Redden, 2017, p.2). Neoliberal initiatives do not generate economic growth. Rather they transfer assets and wealth from the mass of the population to economic elites. In Australia, a clear trend of rising income inequality since the 1980 's, can be discerned. "Real average hourly and whole of life earnings have declined and Australians recently attained the longest working hours in the world... Incomes for the top income decile, however, have risen faster than anywhere in the world” (Redden, 2017, p.3). Redden reports “...there have been no overall significant real-term increases in wealth in Australia since 2006, and virtually no real increases in incomes since 2009 ...the economy enters secular decline and the welfare state is faced with decimation by a literal thousand cuts...”(Redden, 2017, p.12).

The considerable costs in maintaining and growing the 'investor state' directly block the significant social spending essential to 'closing the gap'. So, what are the implications of depending on the state to protect Aboriginal and Torres Strait Islander rights if the state itself constitutes the material embodiment of colonial, patriarchal power? Both patriarchy and colonialism demand passivity and meekness on the part of the oppressed, ensuring silence will lead to continued abuses. Looking to a capitalist system to solve the problems created by a capitalist system is utterly doomed. Capitalist accumulation remains dependent on colonial dispossession. The expansion of capitalism in Australia is contingent on the continued acquisition of land and resources? 


\section{CONCLUSION}

In settler colonial states, indigenous rights and governances are at odds with the prevailing order. Settler colonialism continues to cause harm in the present. Decolonization in the settler colonial context involves action that disrupts settler colonization, works towards the repatriation of land, and recognizes how land has multiple layers of meaning. There is a need to decolonize the political and legislative structures of government and to decolonize knowledge and mindsets. Revolutionary change needs to be a permanent process, searching and seeking out solutions to problems in innovative ways, developing a model for change which is built through grass roots activity rather than legislated or decreed. As August (2013) noted, "A revolution or movement cannot be innovative if it is limited by static structures... structures fixed in time... can act as a detriment to the various daily interventions by the people at all levels... applied to all systems...in different ways" (August 2013, p.10-11). This author believes there are important lessons to be learned from Cuba. Constructive change lies in the active, conscious and ongoing participation of all the people at grass roots level. We need to explore the relationships and connections that may lead to continuous decolonization.

Decolonization demands an Indigenous framework and a centring of indigenous land, indigenous sovereignty, and indigenous ways of thinking and being. For all Australians to flourish, capitalism must be overcome. For this to happen we all need to actively participate in collective alternatives to our current systems. 


\section{REFERENCES}

August, A. (2013). Cuba and its Neighbours: Democracy in Motion. New York and London: Zed books.

Australian Institute of Health and Welfare (2017). Health-adjusted life expectancy in Australia: expected years lived in full health 2011. Australian Burden of Disease Study series no.16. BOD 17. Canberra: AIHW.

Australian Government Department of Home Affairs, Fact Sheet - Abolition of the 'White Australia' Policy. https://www.homeaffairs.gov.au/about/corporate/ information/fact

Blackburn, R. (1988). The Overthrow of Colonial Slavery 1776-1848. London: Penguin Randon House.

Castro, F., \& Ramonet, I. (2006). Fidel Castro: My Life. New York: Scribner. Close the Gap Campaign Steering Committee for Indigenous Health Equality (2018). A ten-year review: the Closing the Gap Strategy and Recommendations for reset. The Close the Gap Campaign Committee. February.

Collard, K. (2000). Aboriginal culture. In Dudgeon, P., Garvey, D., \& Pickett, H., (Eds.) Working with Indigenous Australians: A Handbook for Psychologists ( $\mathrm{p}$. 43-51). Curtin Indigenous Research Centre: Gunada Press.

Credit Suisse Global Wealth Report (2016). Global Wealth Report. Switzerland: Credit Suisse AG.

de Costa, R. \& Clark, T. (2011). Exploring non-Aboriginal Attitudes towards Reconciliation in Canada: The Beginnings of Targeted Focus Group Research. In A. Mathur, J. Dewar \& M. DeGagne (2011). Cultivating Canada: Reconciliation through the Lens of Cultural Diversity. Ottawa, Ontario: Aboriginal Healing Foundation.

Dudgeon, P. (2000). Indigenous identity. In P. Dudgeon, D. Garvey \& H. Pickett (Eds.) Working with Indigenous Australians: A Handbook for Psychologists. (p. 43-51). Curtin Indigenous Research Centre: Gunada Press.

Dudgeon, P., Wright, M., Paradies, Y., Garvey, D. \& Walker, I. (2014). Aboriginal Social, Cultural and Historical Contexts. In P. Dudgeon, Milroy \& R. Walker (Eds.). Working Together: Aboriginal and Torres Strait Islander Health and Wellbeing Principles and Practice, (p. 3-18). Barton ACT: Commonwealth of Australia. 
Egan, G. (2010). ( $9^{\text {th }}$ ed.) The Skilled Helper: A Problem-Management and Opportunity Development Approach to Helping. Australia: Thomson Brooks/ Cole.

First Nation National Constitutional Convention (May, 2017). Uluru Statement from the Heart.

Frankenberg, R. (1993). White women: race matters: The social construction of whiteness. Minneapolis: University of Minnesota Press. https://doi.org/10.4324/9780203973431

Georgatos, G. (2013). Quality of life for Australians $2^{\text {nd }}$ only to Norway, but for Aboriginal peoples $122^{\text {nd }}$. The Stringer, June $16^{\text {th }}, 2013$.

Gott, R. (2004). Cuba: A new history. New Haven and London: Yale University Press.

Gott, R. (2011). Britain's empire: Resistance, repressions and revolt. London: Verso. Green, M.J. \& Sonn, C.C. (2006). Problematising the Discourses of the Dominant: Whiteness and Reconciliation. Journal of Community \& Applied Social Psychology, 16: 379-395. https://doi.org/10.1002/casp.882

Hunter, E. (1993). Aboriginal Health and History: Power and Prejudice in Remote Australia. UK: Cambridge University Press. https://doi.org/10.1017/CBO9780511518188

Jenkins, S. (2015). Rehabilitating Psychology in Australia: The Journey from Colonising Agent to Cultural Broker. Psychotherapy and Politics International, 13(2), 115-128. https://doi.org/10.1002/ppi.1351

London, H. (1970). Non-white immigration and the "white Australian" policy. New York: NewYork University Press.

Main, A. (2013). Aussies top world's wealthiest per capita, Credit-Suisse reports finds. The Australian' $9^{\text {th }}$ October, 2013.

Marr, A. (2012). A History of the World. London: Pan Books.

Marx, K. (1920). The Poverty of Philosophy. Chicago: Charles H. Kerr \& Company (first published 1847), original title Misère de la philosophie.

McQuire, A. (2013). Legal service slams WA Government's "despicable" plans for mandatory sentencing. NewsTracker, February 26, 2013.

Muller, L. (2007). De-colonization: reflections and implication for social work practice. Communities, Children and Families Australia, 31(1), 79-84.

Muller, L. (2014). A Theory for Indigenous Australian Health and Human Service Work: Connecting Indigenous knowledge and practice. Sydney: Allen \& Unwin. 
Paradies, Y. \& Cunningham, J. (2009). Experiences of racism among urban Indigenous Australians: findings from the DRUID study. Ethnic and Racial Studies, 32(3), 548-573. https://doi.org/10.1080/01419870802065234

Pilger, J. (2014). Another stolen generation: how Australia still wrecks Aboriginal families. The Guardian, March 22, 2014.

Redden, G. (2017). John Howard's Investor State: Neoliberalism and the Rise of Inequality in Australia. Critical Sociology, 45(4-5), 713-728. https://doi.org/10.1177/0896920517745117

Swiss, D. J. (2010). The Tin Ticket: The Heroic Journey of Australia's Convict Women. New York: Berkley Books.

Tatz, C. (1999). Genocide in Australia. Canberra: Australian Institute of Aboriginal and Torres Strait Islander Studies.

Smith, L. T. (1999). Decolonizing Methodologies: Research and Indigenous Peoples. Dunedin: University of Otago Press.

Vickers, A. (2005). A History of Modern Indonesia. Cambridge: University Press. https://doi.org/10.1017/CBO9780511801020

Watson, I. (2007). Settled and unsettled spaces: Are we free to roam?. In MoretonRobinson, A. (Eds.). Sovereign Subjects. Crows Nest: Allen \& Unwin. 